This Accepted Author Manuscript is copyrighted and published by Elsevier. It is posted here by agreement between Elsevier and University of Brasilia. Changes resulting from the publishing process - such as editing, corrections, structural formatting, and other quality control mechanisms - may not be reflected in this version of the text. The definitive version of the text was subsequently published in [Virus Research, Volume 130, Issues 1-2, December 2007, Pages 182-192, doi:10.1016/j.virusres.2007.06.010].You may download, copy and otherwise use the AAM for non-commercial purposes provided that your license is limited by the following restrictions:

(1) You may use this AAM for non-commercial purposes only under the terms of the CC-BY-NCND license.

(2) The integrity of the work and identification of the author, copyright owner, and publisher must be preserved in any copy.

(3) You must attribute this AAM in the following format: [agreed attribution language, including link to CC BY-NC-ND license + Digital Object Identifier link to the published journal article on Elsevier's ScienceDirect ${ }^{\circledR}$ platform].

Este Manuscrito do Autor Aceito para Publicação (AAM) é protegido por direitos autorais e publicado pela Elsevier. Ele esta disponível neste Repositório, por acordo entre a Elsevier e a Universidade de Brasília. As alterações decorrentes do processo de publicação - como a edição, correção, formatação estrutural, e outros mecanismos de controle de qualidade - não estão refletidas nesta versão do texto. A versão definitiva do texto foi posteriormente publicado em [Virus Research, Volume 130, Número 1-2, Dezembro de 2007, Páginas 182-192, doi:10.1016/j.virusres.2007.06.010]. Você pode baixar, copiar e utilizar de outra forma o AAM para fins não comerciais, desde que sua licença seja limitada pelas seguintes restrições:

(1) Você pode usar este AAM para fins não comerciais apenas sob os termos da licença CC- BYNC-ND.

(2) A integridade do trabalho e identificação do autor, detentor dos direitos autorais e editor deve ser preservado em qualquer cópia.

(3) Tem de atribuir este AAM no seguinte formato: [acordo na linguagem atribuída, incluindo o link para CC BY-NC-ND licença Digital + DOI do artigo publicado na revista Elsevier ScienceDirect ${ }^{\circledR}$ da plataforma]. 


\title{
An Anticarsia gemmatalis multiple nucleopolyhedrovirus mutant, vApAg, induces hemocytes apoptosis in vivo and displays reduced infectivity in larvae of Anticarsia gemmatalis (Hübner) (Lepidoptera: Noctuidae)
}

\author{
Eni Braga da Silveira \\ Bruno Arrivabene Cordeiro \\ Bergmann Morais Ribeiro \\ Maria Elita Batista de Castro \\ Elisa Filgueiras Soares \\ Sônia Nair Báo
}

\begin{abstract}
An Anticarsia gemmatalis multiple nucleopolyhedrovirus (AgMNPV) mutant, vApAg, induces apoptosis in a cell culture derived from Anticarsia gemmatalis (UFL-AG-286), reducing viral progeny. We have investigated apoptosis induction in vivo by vApAg in A. gemmatalis larvae and its correlation to infectivity reduction. LC50, LD50, LT50 and the mean time to death of larvae were determined for VApAg and AgMNPV. Apoptosis was accessed for hemocytes of infected larvae using light and transmission electron microscopy. All types of hemocytes can be infected by vApAg. After $12 \mathrm{~h}$ post-infection (h p.i.), typical cellular modifications associated to nucleopolyhedrovirus infection were observed. Apoptosis becomes evident after $24 \mathrm{~h}$ p.i., and massive after $72 \mathrm{~h}$ p.i. Necrosis of infected cells was also observed. Despite cell death, hemocytes produced budded viruses and polyhedra. PI and gh1-type hemocytes presented phagocytic activity. Agarose gel electrophoresis revealed fragmentation of hemocytes DNA at late times post-infection. The LC50 and LD50 were between five- and six-fold higher for VApAg. The LT50 and the mean time to death were higher for VApAg in a same treatment or for a similar mortality induced by AgMNPV. These results show correlation of apoptosis and the reduced infectivity of VApAg in A. gemmatalis larvae.
\end{abstract}

Keywords: Apoptosis; Baculovirus; Hemocytes; Infectivity reduction; Lepidoptera; Ultrastructure

\footnotetext{
Abbreviations:

AcMNPV, Autographa californica multiple nucleopolyhedrovirus; AgMNPV, Anticarsia gemmatalis multiple nucleopolyhedrovirus; BV, budded virus; DIC, differential interferential contrast; gh1, granular hemocyte type 1; gh2, granular hemocyte type 2; h p.i., hours post-infection; IAP, inhibitor of apoptosis; LC50, lethal concentration to kill $50 \%$ of individuals in a bioassay; LD50, lethal dose to kill $50 \%$ of individuals in a bioassay; LT50, time to kill $50 \%$ of individuals in a bioassay; PFU, plaque forming unit; PIBs, polyhedral inclusion bodies; pl, plasmatocyte; pr, prohemocyte; sph, spherulocyte; TEM, transmission electron microscopy
} 


\section{Introduction}

Apoptosis is a kind of programmed cell death conserved among metazoans, playing important functions in immunity, development, cell differentiation and tissue homeostasis. Apoptosis can be triggered by diverse stimuli, which results in cysteine protease activation that drives cell shrinkage, DNA cleavage by endonucleases, and cell fragmentation into apoptotic bodies (Ashe and Berry, 2003 and Kerr et al., 1972).

Apoptosis regulation by members of the family Baculoviridae has been extensively studied since the beginning of the 1990s, when a mutant of Autographa californica multiple nucleopolyhedrovirus (AcMNPV) was shown to induce apoptosis in a cell line derived from Spodoptera frugiperda ( Clem et al., 1991).

Two types of apoptosis inhibitors are described for baculoviruses: P35 protein and inhibitor of apoptosis (IAP) proteins. P35 is a broad-spectrum caspase inhibitor present in baculoviruses and more recently found in entomopoxviruses, while IAP constitutes a protein family whose members are described in baculoviruses, insects, nematodes and humans (Clarke and Clem, 2003a, Clem, 2001 and Means et al., 2007).

Mutation in p35 and iap or the impairment of their expression, results in premature death and reduction in viral progeny production in specific hosts, as demonstrated mainly for AcMNPV and Bombyx mori nucleopolyhedrovirus (BmNPV) ( Clarke and Clem, 2003a and Clem, 2001). In other cases, despite presenting intact anti-apoptotic genes, baculoviruses like AcMNPV induce apoptosis and display reduced infectivity and propagation in a specific host, as Spodoptera litura larvae ( Zhang et al., 2002). Wild-type Heliothis armigera single nucleopolyhedrovirus (HaSNPV) induces apoptosis in a cell line derived from Trichoplusia ni ( Dai et al., 1999). This demonstrates that putative viral strategies to counteract apoptosis are one of the determinants of baculovirus host range.

Although it has long been reported that baculoviruses lacking an anti-apoptotic gene have a reduced infectivity in vivo, to date, there are only three reports concerning baculovirus induction of apoptosis in lepidopteran larvae (Clarke and Clem, 2003b, Silveira et al., 2005 and Zhang et al., 2002). Studies in this field allowed the recognition of apoptosis as an important anti-viral response in insects, which lack acquired immunity elements such as antibodies, for example (Clarke and Clem, 2003a and Clem, 2001).

The baculovirus Anticarsia gemmatalis multiple nucleopolyhedrovirus (AgMNPV) has been used for more than 20 years in Brazil to control the velvetbean caterpillar, Anticarsia gemmatalis (Hübner). It represents an important factor for the reduction in production costs and environmental damages caused by chemical pesticides in soybean (Glycine max) crops ( 
Moscardi, 1999 and Ribeiro et al., 1998). AgMNPV is a rod-shaped, enveloped virus with circular, double-stranded, 132,239 bp DNA genome, pathogenic to lepidopterans, and belongs to the NPV I group ( Grasela and McIntosh, 1998, Johnson and Maruniak, 1989 and Oliveira et al., 2006).

During the construction of a recombinant baculovirus derived from AgMNPV, besides recombinant and non-recombinant viruses, a mutant, $\mathrm{vApAg}$, was obtained. This mutant induces premature death in a cell line highly permissive to AgMNPV (UFL-AG-286) (Sieburth and Maruniak, 1988a) while, in another cell line (BTI-Tn-5B1-4) (Tn-5B) (Granados et al., 1994), it replicates normally. UFL-AG-286 cells infected by vApAg die by apoptosis (Silveira et al., 1999). Despite apoptosis occurrence, budded viruses (BV) and polyhedral inclusion bodies (PIBs) are produced (Silveira et al., 1999), but in a reduced fashion if compared with the progeny obtained by the wild-type virus in the same cell line (Castro and Ribeiro, 2001).

AgMNPV is known to possess at least one type of iap gene related to apoptosis inhibition ( Carpes et al., 2005) (GenBank accession no. AY525121). The gene iap-3 was shown to be disrupted by a transposable element in the vApAg virus (Carpes et al., unpublished), which may be the cause of apoptosis induction in cell culture and in A. gemmatalis larvae.

In this work, we have investigated if the vApAg mutant induces apoptosis in vivo by accessing vApAg infection in A. gemmatalis hemocytes by intrahaemocoelic inoculation. Light and transmission electron microscopy were used to follow the temporal events of infection in hemocytes. Agarose gel electrophoresis was conducted to detect oligonucleosomal fragmentation of hemocytes' DNA. The infectivity was compared between vApAg and AgMNPV by the determination of the mean lethal dose (LD50) for intrahaemocoelic infection, the mean lethal concentration (LC50) for oral infection, the mean lethal time (LT50) and the mean time to death for both.

\section{Materials and methods}

\subsection{Insects and viruses}

A. gemmatalis eggs were provided by Embrapa Recursos Genéticos e Biotecnologia and Embrapa Soja, and reared on artificial diet (Greene et al., 1976) at $27-28^{\circ} \mathrm{C}$, with a $12: 12$ $\mathrm{h}$ dark/light regime. The molts were monitored, and fourth instar larvae (between 0 and $24 \mathrm{~h}$ after molt) were used for all experiments.

AgMNPV isolate 2D (Grasela and McIntosh, 1998) was propagated in UFL-AG-286 cells (Grasela and Mclntosh, 1998 and Sieburth and Maruniak, 1988b). VApAg was propagated in BTI-Tn-5B1-4 (Tn-5B) cells (Granados et al., 1994). Cell cultures were maintained in TC-100 
medium (GIBCO-BRL Life Technologies, Grand Island, NY) supplemented with $10 \%$ fetal bovine serum at $27{ }^{\circ} \mathrm{C}$. Virus inocula were titered by the TCID50 method, following the protocol described by O'Reilly et al. (1992).

AgMNPV-2D and vApAg (PIBs) were obtained from A. gemmatalis larvae, which died by infection with the respective virus. The cadavers were macerated in homogenization buffer and filtered. The filtrate was centrifuged, the pellet resuspended in distilled water and maintained at $-20^{\circ} \mathrm{C}$.

\subsection{Bioassays}

Insects were injected with $10 \mu \mathrm{l}$ of viral inoculum directly into the haemocoel, by using an insulin micro-syringe. Six different doses were used for AgMNPV (0.01, 0.05, 0.1, 1, 10 and 100 PFU) and five for $\operatorname{vApAg}(0.1,1,5,10$ and 100 PFU). Controls were obtained by the inoculation of an equal volume of TC-100 medium (mock-infected). For each treatment, 50 larvae were inoculated. Each larva was reared separate in a plastic cup.

For oral infection, purified PIBs were used in five concentrations for both viruses $(5 \times$ $102,1.5 \times 103,4.5 \times 103,1.35 \times 104,4.05 \times 104 \mathrm{PIBs} / \mathrm{ml})$. For each treatment 30 larvae were used, which were maintained in plastic cups in groups of three individuals per cup. Each cup contained $5 \mathrm{ml}$ of artificial diet, free of nipagin and formol, covered by $150 \mu \mathrm{l}$ of viral inoculum. For controls, distilled water was used instead of viral inoculum.

Development and mortality were analyzed every day up to the end of the experiment. Individuals that pupated were considered to have survived the infection. Deaths attributed to inoculation trauma were not considered. Larvae were considered dead if they did not move after mechanical stimulation. A sample of hemolymph was taken from dead larvae to confirm baculovirus infection by finding PIBs under light microscopy.

Mortality data were submitted to Probit analysis (Finney, 1971) to estimate the LD50 for intrahaemocoelic infection, the LC50 for oral infection, and the LT50 for specific doses/concentrations for both ways of infection, as well associated parameters (95\% fiducial limit, slope, $\chi 2$ ) for both viruses. For statistical significance between AgMNPV and vApAg, regarding the LD50, LC50 and LT50 values, the non-overlapping of the $95 \%$ fiducial limits was considered as evidence of significant differences. The mean time to death was determined according to Morales et al. (2001). 


\subsection{Light and transmission electron microscopy}

Hemolymph samples of insects infected intrahaemocoelically with $20 \mu \mathrm{l}$ of $\mathrm{vApAg}$ inoculum (108 PFU/ml), as described above, were collected in anticoagulant buffer (98 mM $\mathrm{NaOH}, 186 \mathrm{mM} \mathrm{NaCl}, 1.7 \mathrm{mM}$ EDTA, $41 \mathrm{mM}$ citric acid, pH 4.5) (Mead et al., 1986) after different times post-infection $(12,24,48$ and $72 \mathrm{~h}$ p.i.) and observed under differential interferential contrast (DIC) in an Axiophot Zeiss light microscope. For transmission electron microscopy, the samples were fixed for $30 \mathrm{~min}$ (2\% glutaraldehyde, $2 \%$ paraformaldehyde in $0.1 \mathrm{M}$ sodium cacodylate buffer $\mathrm{pH} 7.4$ with $5 \%$ sucrose), centrifuged at $750 \times \mathrm{g}$ for $5 \mathrm{~min}$, the pellet washed in the same buffer, post-fixed ( $1 \%$ osmium tetroxide, $0.8 \%$ potassium ferricyanide in the same buffer), contrasted in block with $0.5 \%$ uranyl acetate, dehydrated in acetone, and embedded in Spurr's resin. The ultrathin sections were contrasted with uranyl acetate/lead citrate and observed in a TEM JEOL 100C and JEOL 1011 at $80 \mathrm{kV}$.

\subsection{Hemocyte identification}

Larval A. gemmatalis hemocyte types were identified by structural and ultrastructural characteristics described previously ( Silveira et al., 2003 and Silveira et al., 2004).

\subsection{DNA extraction and oligonucleosomal fragmentation assay}

Hemolymph samples obtained from insects inoculated with $20 \mu \mathrm{l}$ of viral inoculum (108 PFU/ml), as described above, were collected in PBS pH 7.2 at 12, 24, 48 and 72 h p.i., and submitted to DNA extraction according to Aljanabi and Martinez (1997). In brief, samples were centrifuged at $1300 \times \mathrm{g}$ for $6 \mathrm{~min}$, the pellet resuspended in $400 \mu \mathrm{l}$ lysis buffer $(0.4 \mathrm{M} \mathrm{NaCl}, 10$ $\mathrm{mM}$ Tris- $\mathrm{HCl}$ pH 8.0, $2 \mathrm{mM}$ EDTA pH 8.0), $1 \mathrm{mg} / \mathrm{ml}$ proteinase $\mathrm{K}, 2 \% \mathrm{SDS}$ and incubated at $50{ }^{\circ} \mathrm{C}$ for $1 \mathrm{~h}$. Then, $400 \mu \mathrm{l}$ of $6 \mathrm{M} \mathrm{NaCl}$ were added, the tubes were gently vortexed and centrifuged at $16,000 \times \mathrm{g}$ for $20 \mathrm{~min}$. Equal volume of isopropanol was added to the supernatant, it was homogenized and maintained at $-20{ }^{\circ} \mathrm{C}$ for at least $1 \mathrm{~h}$. The DNA was precipitated by centrifugation at $16,000 \times \mathrm{g}$ for $20 \mathrm{~min}$, washed with $70 \%$ ethanol, dried and resuspended in 50 $\mu \mathrm{ITE}$ (10 mM Tris-HCl, $1 \mathrm{mM}$ EDTA pH 8.0). Ribonuclease A was added to a final concentration of $40 \mu \mathrm{g} / \mathrm{ml}$. DNA concentration was estimated according to phage $\lambda$ standards in $0.8 \%$ agarose gel eletrophoresis. Approximately $2 \mu \mathrm{g}$ of each sample were analyzed in a $3 \%$ agarose gel at 80 $V$ and visualized under UV radiation after incubation with ethidium bromide. 


\section{Results}

\subsection{Bioassays}

For intrahaemocoelic infection, it was obtained LD50 values of 0.744 and 4.17 PFU/larva for AgMNPV and $\mathrm{VApAg}$, respectively, which means that the mutant $\mathrm{VApAg}$ requires around a six-fold higher dose than the wild-type virus to kill $50 \%$ of larvae in a bioassay (Table 1). The LT50 (Table 2) values obtained for doses that result in, approximately, 50 and $100 \%$ of mortality show that vApAg requires between two and three more days than AgMNPV to kill $50 \%$ of larvae when using doses that result in similar mortalities for both viruses. The mean time to death (Table 3 ) values reveal that vApAg requires between two and four more days than AgMNPV to kill larvae using the same dose.

Table 1

Mean lethal dose (LD50), 95\% fiducial limits of the LD50 (95\% FL), slope and Chi-square (2) values for Anticarsia gemmatalislarvae infected with AgMNPV and $\mathrm{VApAg}$ by intrahaemocoelic injection of BVs

\begin{tabular}{lllll}
\hline Virus & $\mathrm{LD}_{50}{ }^{\mathrm{a}}$ & $95 \% \mathrm{FL}^{\mathrm{a}}$ & Slope & $\chi^{2}$ \\
\hline AgMNPV & 0.744 & $0.41-1.54$ & 0.96 & $2.29 \mathrm{~ns}$ \\
vApAg & 4.170 & $2.85-6.61$ & 1.46 & $2.24 \mathrm{~ns}$ \\
\hline
\end{tabular}

a Expresses the number of PFU/larva. Non-overlapping 95\% FL is an evidence of significant differences between the LD50 values obtained.

Table 2

Mean lethal time (LT50), 95\% fiducial limits of the LT50 (95\% FL), slope and Chi-square (2) values for A. gemmatalislarvae infected with LD50 higher doses of AgMNPV and vApAg BVs by intrahaemocoelical injection

\begin{tabular}{lcccrl}
\hline Virus & Dose (PFU/larva) & $\mathrm{LT}_{50}{ }^{\mathrm{a}}$ & $95 \% \mathrm{FL}^{\mathrm{a}}$ & $\mathrm{Slope}$ & $\chi^{2}$ \\
\hline AgMNPV & 1 & 9.75 & $8.98-11.06$ & 5.83 & $3.41 \mathrm{~ns}$ \\
& 100 & 5.72 & $5.47-6.00$ & 11.45 & $7.72 \mathrm{~ns}$ \\
\multirow{2}{*}{ vApAg } & 5 & 12.12 & $11.31-13.69$ & 7.53 & $2.76 \mathrm{~ns}$ \\
& 100 & 9.1 & $8.7-9.48$ & 9.20 & $1.31 \mathrm{~ns}$ \\
\hline
\end{tabular}

${ }^{a}$ Expresses time in days. Non-overlapping 95\% FL is an evidence of significant differences between the LT50 values obtained. 
Table 3

Mortality and mean time to death of A. gemmatalis larvae intrahaemocoelically infected with AgMNPV and vApAg BVs

\begin{tabular}{lcccrc}
\hline Virus & Dose (PFU/larva) & Number of dead larvae ${ }^{\mathrm{a}}$ & \multicolumn{1}{c}{$n^{\mathrm{a}}$} & ${\text { Mortality }(\%)^{\mathrm{a}}}^{\text {Mean time to death (days) }}$ \\
\hline AgMNPV & 0.1 & $10.33 \pm 0.58$ & $42 \pm 1$ & $24.60 \pm 0.90$ & $8.39 \pm 1.85$ \\
& 1 & $20 \pm 3.61$ & $38.67 \pm 6.81$ & $51.91 \pm 4.82$ & $7.14 \pm 0.93$ \\
vApAg & 100 & $36.67 \pm 4.04$ & $38 \pm 3.46$ & $96.43 \pm 4.29$ & $5.87 \pm 0.40$ \\
& 0.1 & $2 \pm 2.65$ & $36.33 \pm 4.16$ & $4.86 \pm 5.86$ & $10.60 \pm 0.57$ \\
& 1 & $13 \pm 3$ & $43 \pm 3$ & $30.51 \pm 8.59$ & $10.95 \pm 2.45$ \\
& 100 & $40.67 \pm 7.37$ & $41.67 \pm 6.66$ & $97.41 \pm 2.51$ & $9.33 \pm 2.37$
\end{tabular}

a Values correspond to media and standard deviation for three repetitions. Deaths attributed to injection trauma were not considered, causing variable $n$.

Table 4

Mean lethal concentration (LC50), 95\% fiducial limits of the LC50 (95\% FL), slope and Chisquare (2) values for A. gemmatalis larvae orally infected with AgMNPV and vApAg

\begin{tabular}{lcrll}
\hline Virus & $\mathrm{LC}_{50}{ }^{\mathrm{a}}$ & \multicolumn{1}{c}{$95 \% \mathrm{FL}^{\mathrm{a}}$} & Slope & $\chi^{2}$ \\
\hline AgMNPV & 723.10 & $185.92-1382.64$ & 1.86 & 5.83 \\
vApAg & 3718.07 & $1686.91-7377.35$ & 0.75 & 4.72 \\
\hline
\end{tabular}

a Expresses the number of PIBs/ml. Non-overlapping 95\% FL is an evidence of significant differences between the LC50 values obtained.

Table 5

Mean lethal time (LT50), 95\% fiducial limits of the LT50 (95\% FL), slope and Chi-square (2) values for A. gemmatalislarvae orally infected with LC50 higher doses of AgMNPV and vApAg PIBs

\begin{tabular}{llrrrr}
\hline Virus & $\begin{array}{l}\text { Concentration } \\
(\mathrm{PIBs} / \mathrm{ml})\end{array}$ & $\mathrm{LT}_{50} \mathrm{a}$ & $95 \% \mathrm{FL}^{\mathrm{a}}$ & Slope & $\chi^{2}$ \\
\hline AgMNPV & 4,500 & 8.30 & $7.64-8.89$ & 6.70 & 6.47 \\
& 13,500 & 7.40 & $6.65-8.01$ & 5.57 & 3.77 \\
& 40,500 & 5.91 & $4.88-6.57$ & 6.99 & 7.14 \\
vApAg & 4,500 & 14.08 & $12.44-17.55$ & 6.34 & 21.18 \\
& 13,500 & 10.63 & $9.95-11.44$ & 5.41 & 8.24 \\
& 40,500 & 8.83 & $8.24-9.50$ & 4.90 & 3.27 \\
\hline
\end{tabular}

${ }^{a}$ Expresses time in days. Non-overlapping 95\% FL is an evidence of significant differences between the LT50 values obtained.

For oral infection, the LC50 values obtained were 723.1 and $3718.07 \mathrm{PIBs} / \mathrm{ml}$ for AgMNPV and $\mathrm{VApAg}$, respectively, which reveals that a five-fold higher concentration is needed for the mutant virus to kill $50 \%$ of larvae in a bioassay (Table 4). The LT50 values presented significant differences between the viruses for the same concentration, showing that $\mathrm{vApAg}$ requires between three and six more days to kill $50 \%$ of larvae in comparison to AgMNPV (Table 5). For a similar LT50 (around 8 days), vApAg requires a 9-fold higher concentration than AgMNPV (Table 5). For the same dose, the mean time to death (Table 6) values reveal that VApAg requires between one and two more days than AgMNPV to kill larvae. 
In comparison to AgMNPV, vApAg produced diminished larval mortality for all the concentrations tested, for both, intrahaemocoelic and oral infection (Table 3 and Table 6). For intrahaemocoelic infection, a maximum reduction of approximately $80 \%$ was obtained for 0.1 PFU/larvae (Table 3). For oral infection, the maximum reduction was around $40 \%$, obtained for $4500 \mathrm{PIBs} / \mathrm{ml}$ (Table 6).

\subsection{Light and transmission electron microscopy (TEM)}

Six hemocyte types were recognized in A. gemmatalis larvae based on structural and ultrastructural characteristics, as described previously ( Silveira et al., 2003 and Silveira et al., 2004). They were prohemocytes (pr), plasmatocytes (pl), granular hemocytes type 1 (gh1), granular hemocytes type 2 (gh2), oenocytoids (oe), and spherulocytes (sph). The ultrastructure described originally for each cell type was observed in controls (not shown).

By DIC, the hemocytes morphology was similar to control, after 12 and $24 \mathrm{~h}$ p.i. with a small number of fragmented cells (Fig. 1A). By the TEM, between 12 and $24 \mathrm{~h}$ p.i. (Fig. 2A-D) nuclei were hypertrophied, with a slight folding of the nuclear envelope. The heterochromatin was marginated and the virogenic stroma became evident, presenting nucleocapsids assembling. In the nuclear periphery, nucleocapsids were enveloped by membranous profiles. In this period, fibrillar aggregates appeared and accumulated in the cytoplasm (Fig. 2D). Nucleocapsids were directed to the cytoplasm by budding through the nuclear envelope, and BVs were seen to protrude at the plasma membrane (Fig. 2B and C). Chromatin condensation was observed for some cells (not shown).

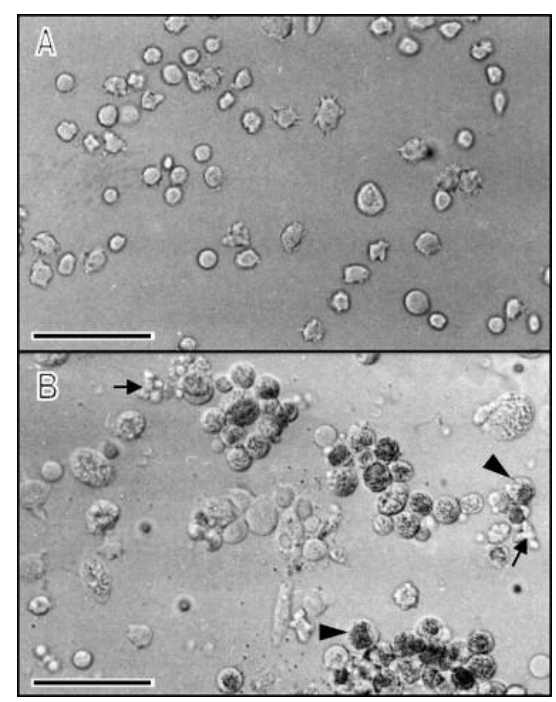

Fig. 1. DIC micrographs of Anticarsia gemmatalis larval hemocytes infected with vApAg: (A) $12 \mathrm{~h}$ p.i.; (B) $72 \mathrm{~h}$ p.i. Arrowheads, cells presenting PIBs and arrows, apoptotic bodies. Bars represent $65 \mu \mathrm{m}$. 


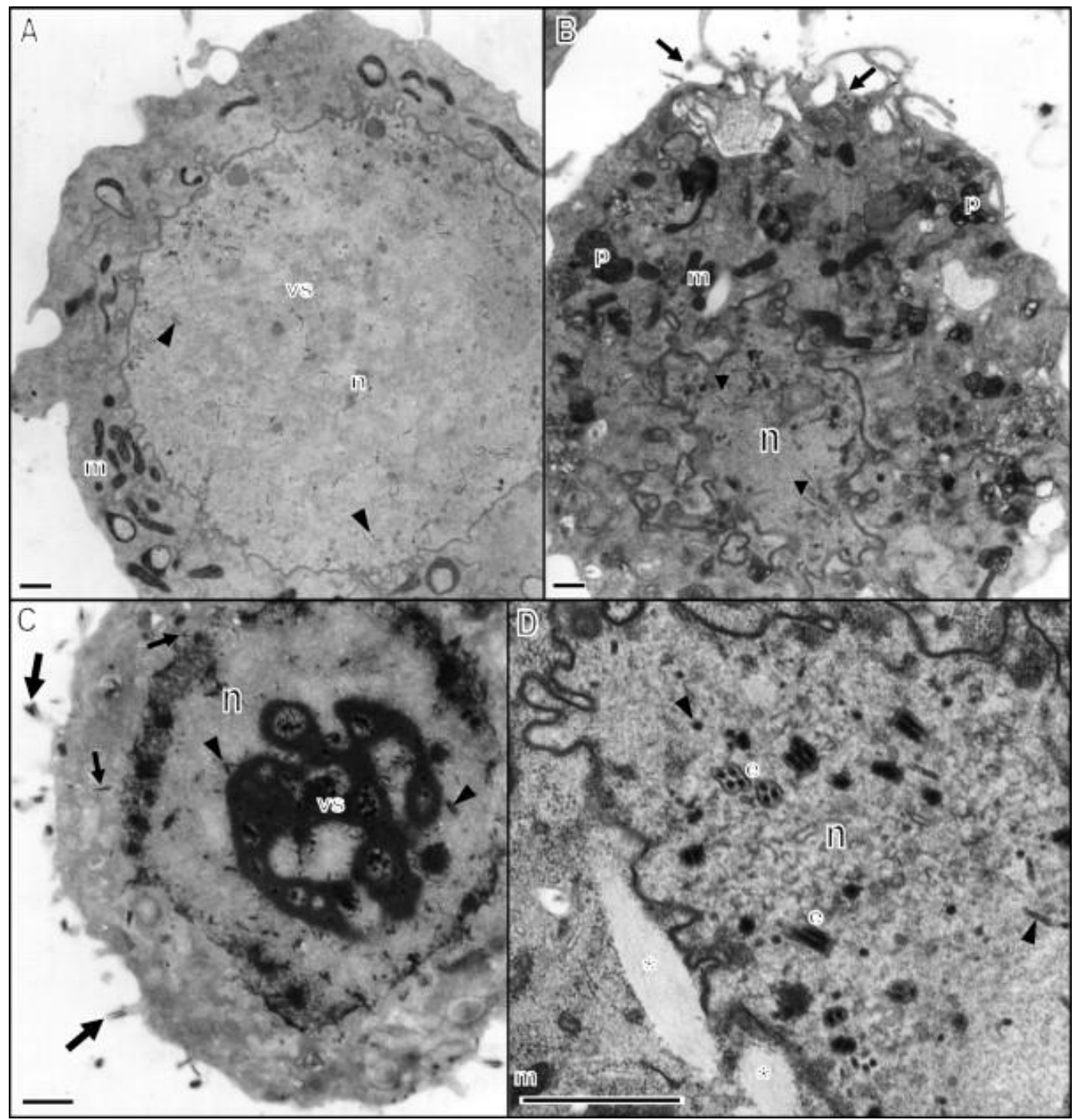

Fig. 2. Transmission electron micrographs of A. gemmatalis larval hemocytes after 12 and $24 \mathrm{~h}$ p.i. with vApAg. (A) $12 \mathrm{~h}$ p.i. Oenocitoid, presenting a hypertrophied nucleus ( $\mathrm{n}$ ) containing an immature virogenic stroma (vs). Arrowheads, nucleocapsids; n, nucleus and m, mitochondria. (B) 12 h p.i. Granular hemocyte type 1 presenting some BVs budding at the plasma membrane (arrows) and phagolysosomes (p). Arrowheads, nucleocapsids; $n$, nucleus and $\mathrm{m}$, mitochondria. (C) $24 \mathrm{~h}$ p.i. Putative prohemocyte displaying a mature virogenic stroma (vs), nucleocapsids transportation through the cytoplasm (small arrows) and intense BVs budding at the plasma membrane (large arrows). Arrowheads, nucleocapsids; n, nucleus. (D) $24 \mathrm{~h}$ p.i. Plasmatocyte displaying nucleocapsids envelopment by membranous profiles (e) and cytoplasmic fibrillar aggregates $\left({ }^{*}\right)$. Arrowheads, nucleocapsids; $n$, nucleus and m, mitochondria. Bars represent $1 \mu \mathrm{m}$.

After 48 and $72 \mathrm{~h}$, an extensive number of fragmented cells and PIBs could be observed by DIC (Fig. 1B). By TEM, PIBs assembling, extensive nuclear and cytoplasmic fibrillar aggregates were visualized (Fig. 3 and Fig. 4). For some cells, the nuclear envelope was greatly expanded, forming a convoluted network through the adjacent cytoplasm (Fig. 4A). These expanded nuclei were sometimes shown to be broken, causing the mix of nuclear and cytoplasmic compartments, with the presence of PIBs and groups of unenveloped nucleocapsids just beneath the plasma membrane (Fig. 4B and C). 


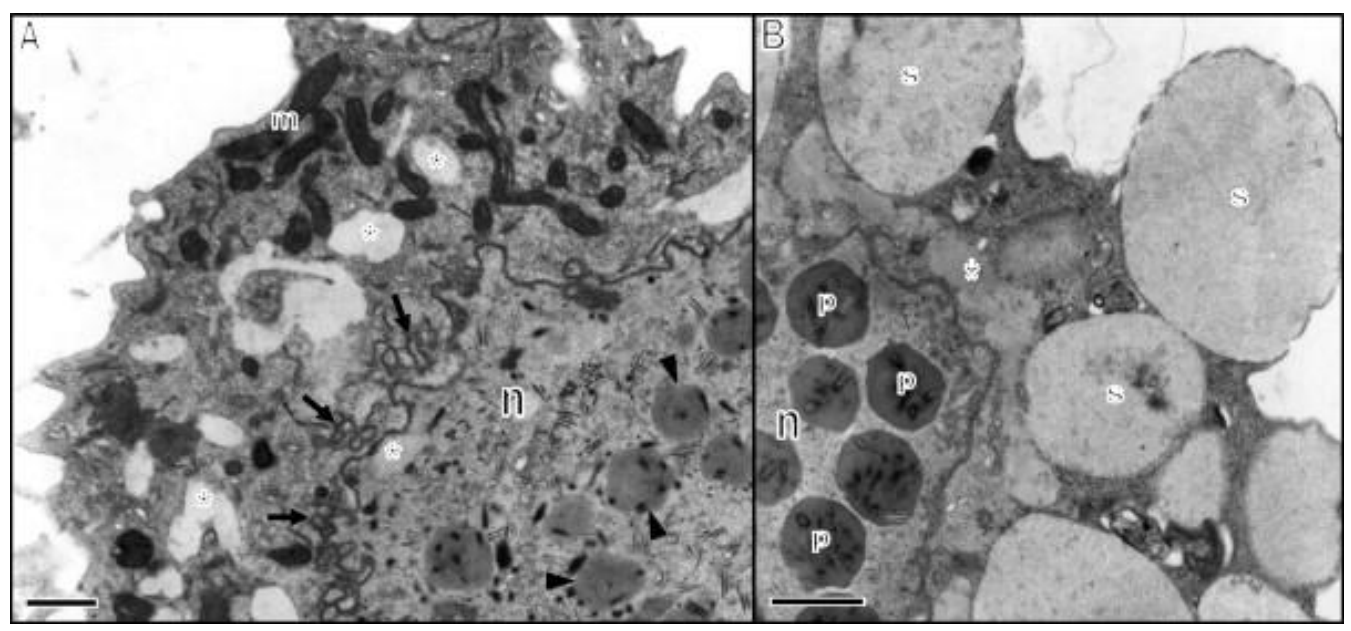

Fig. 3. Transmission electron micrographs of A. gemmatalis larval hemocytes after 48 and $72 \mathrm{~h}$ p.i. with vApAg. (A) $72 \mathrm{~h}$ p.i. plasmatocyte presenting nuclear and cytoplasmic fibrillar aggregates $\left({ }^{*}\right)$, nuclear envelope folding (arrows) and PIBs assembling (arrowheads); $n$, nucleus and m, mitochondria. (B) $48 \mathrm{~h}$ p.i. spherulocyte; n, nucleus; $p$, PIBs; s, spherule and (*), fibrillar aggregate. Bars represent $1.5 \mu \mathrm{m}$.

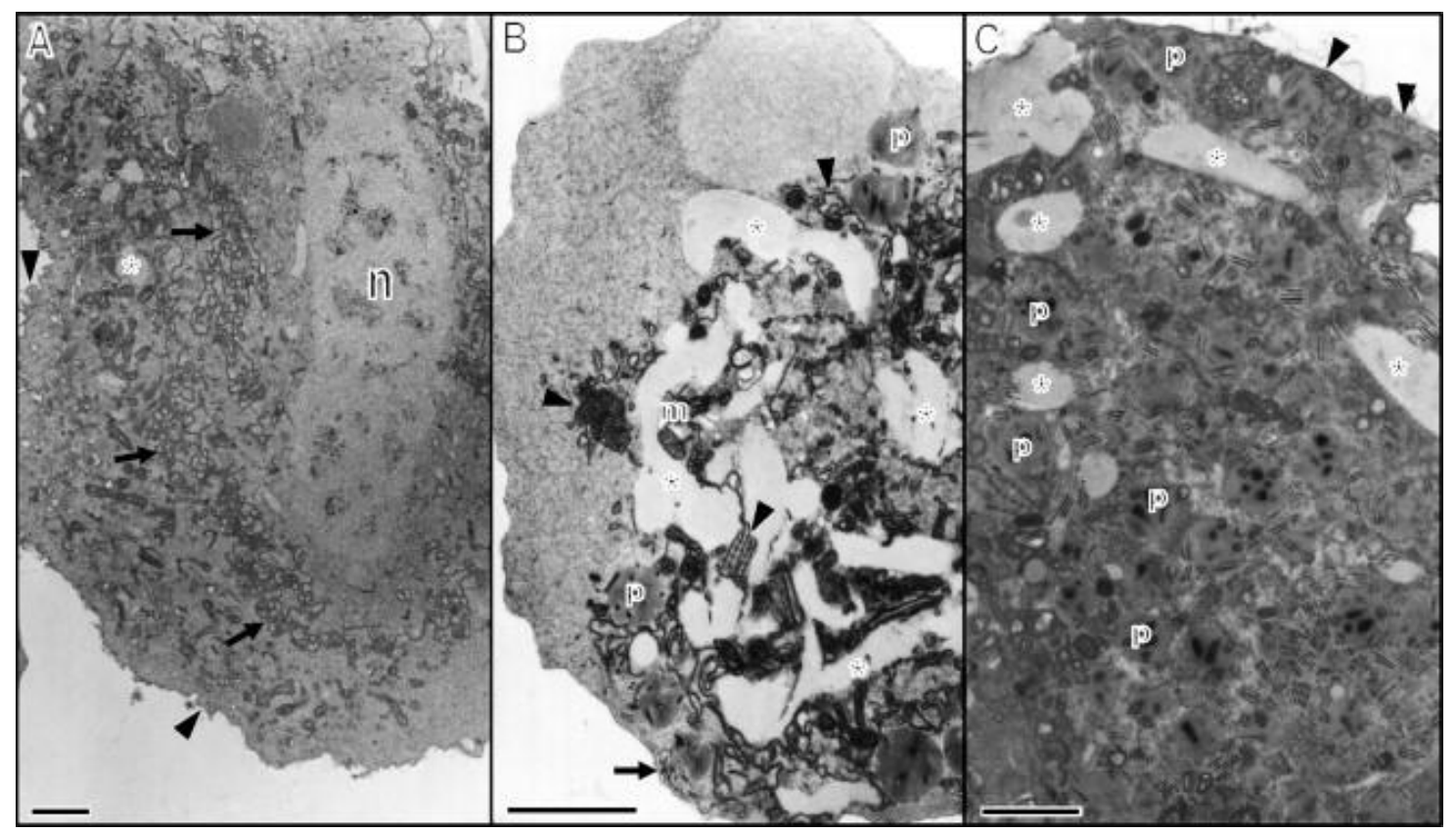

Fig. 4. Transmission electron micrographs of A. gemmatalis larval hemocytes after 48 and $72 \mathrm{~h}$ p.i. with vApAg, which presented cytoplasmic disorganization. (A) $48 \mathrm{~h}$ p.i. unidentified hemocyte. Note the intensely extended nuclear envelope (arrows), and the numerous nucleocapsids in the periphery of the cytoplasm (arrowheads); n, nucleus and (*), fibrillar aggregate. (B) $72 \mathrm{~h}$ p.i. unidentified hemocyte. The nucleus was broken and remnants of the nuclear envelope (arrowheads) were mixed with fibrillar aggregates $(*)$, nucleocapsids (arrows), mitochondria (m) and PIBs (p). (C) $72 \mathrm{~h}$ p.i. unidentified hemocyte. A great number of PIBs ( $p)$ were produced, the nuclear envelope was ruptured, some PIBs (p) and free nucleocapsids (arrowheads) lie beneath the plasma membrane. (*) Fibrillar aggregates. Bars represent $2 \mu \mathrm{m}$.

Endomembranes dilation, plasma membrane blebbing and cell fragmentation into apoptotic bodies were observed at $12 \mathrm{~h}$ p.i., however, they became more frequent at late times post-infection. Apoptosis was observed for cells that did not present viral cytopathic effects, and for infected cells in different phases of viral morphogenesis (Fig. 5A-E). The pattern of cell fragmentation was shown to be variable (Fig. 5A-D). BV entry and intense 
budding were observed for apoptotic cells or apoptotic bodies (Fig. 5B, D and E). It was not possible to detect production of apoptotic bodies for sph, despite their evident infection (Fig. 3 and Fig. 7).

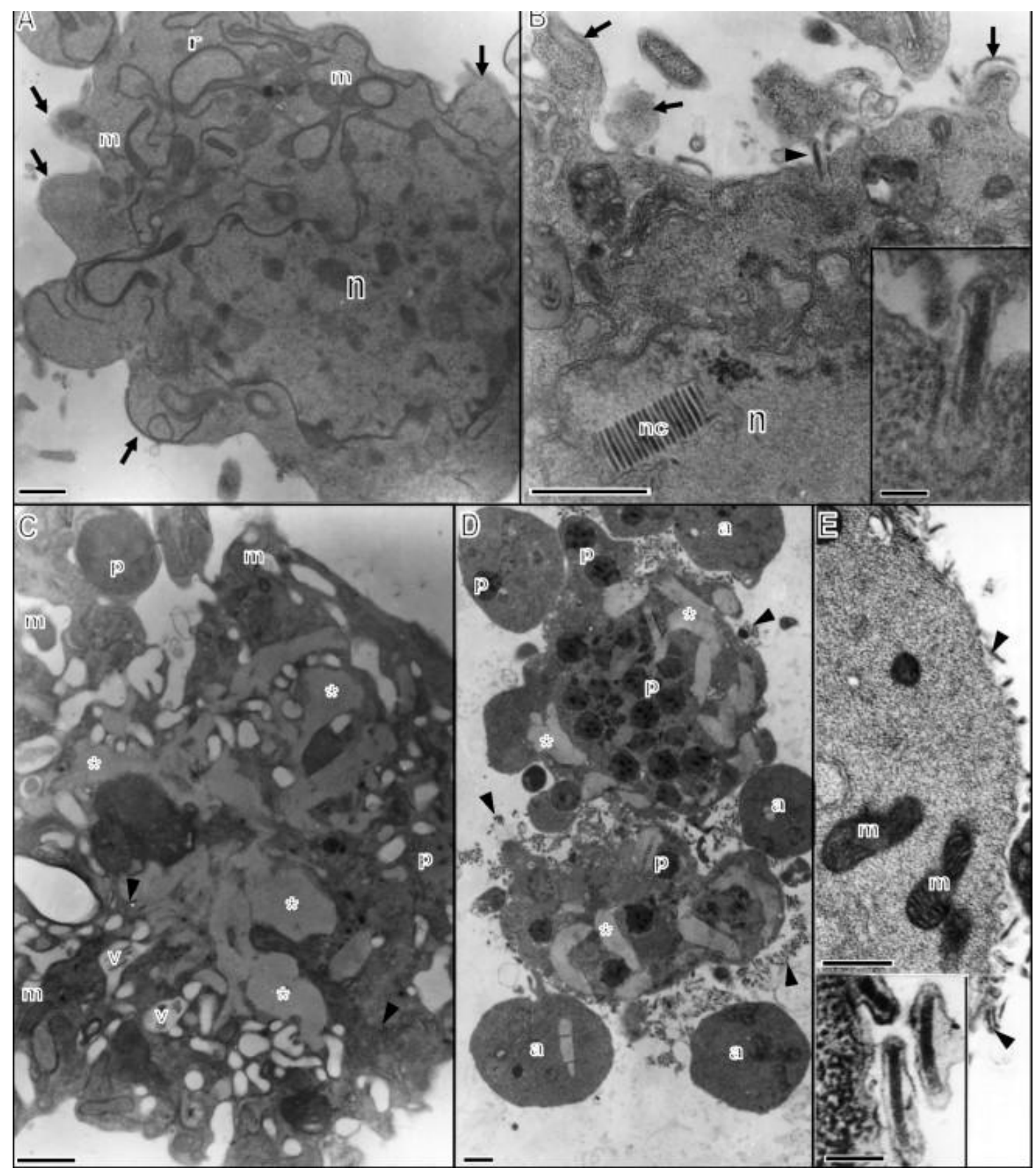

Fig. 5. Transmission electron micrographs of A. gemmatalis larval hemocytes in apoptosis induced by vApAg. (A) A putative prohemocyte presenting surface blebbing (arrows). $n$, nucleus; m, mitochondria and $r$, rough endoplasmic reticulum. (B) Granular hemocyte type 1 . Note the aligned nucleocapsids (nc) in the nucleus ( $n)$, surface blebbing (arrows) and a BV (arrowhead) entering the cell by endocytosis (inset). (C) Plasmatocyte in apoptosis. (*), fibrillar aggregates; arrowheads, nucleocapsids; $v$, vesicles; $p$, PIBs; $m$, mitochondria. (D) Unidentified hemocyte in apoptosis. a, apoptotic bodies; (*) fibrillar aggregates; arrowheads, BVs and p, PIBs. (E) Apoptotic body probably derived from a granular hemocyte type 1. Numerous BVs were budding at the plasma membrane (arrowheads) (inset). m, mitochondria. Bars represent $1 \mu \mathrm{m}$. Insets bars represent $0.2 \mu \mathrm{m}$.

Phagocytic activity was observed at $12 \mathrm{~h} \mathrm{p.i.} \mathrm{for} \mathrm{pl} \mathrm{and} \mathrm{gh1} \mathrm{(Fig.} \mathrm{2B)} \mathrm{and} \mathrm{like} \mathrm{apoptosis}$ events, it became more intense at late times post-infection. These two hemocyte types were 
observed to phagocytose apoptotic bodies, entire cells and free PIBs, but the engulfment of large bodies, such as entire cells, was more common for pl (Fig. 6A-C). Necrosis of infected cells, presenting a mature virogenic stroma or even PIBs, was frequently observed (Fig. 7A and B). All hemocyte types were shown to be infected, but for gh2, this occurred in an extremely low frequency.

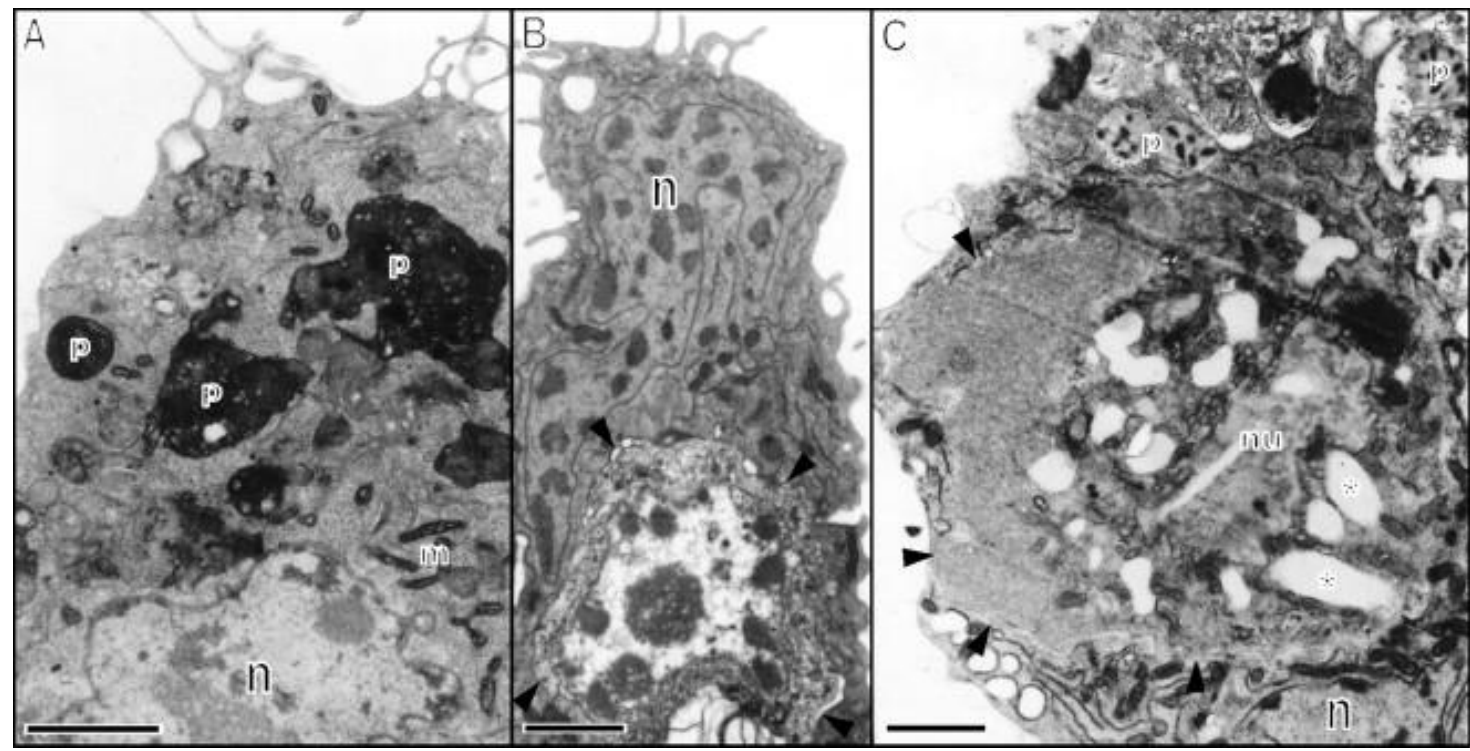

Fig. 6. Phagocytic activity of A. gemmatalis larval hemocytes infected with vApAg. (A) Granular hemocyte type 1 whose phagolysosomes contain cell debris (p). $n$, nucleus and $m$, mitochondria. (B) $A$ plasmatocyte presenting a phagolysosome containing an entire transversal section of a cell (arrowheads). n, plasmatocyte nucleus. (C) A plasmatocyte that engulfed an infected cell (arrowheads indicate the limits of the phagosome). The same cell also has phagocytosed free PIBs (p). $n$, plasmatocyte nucleus, nu, engulfed cell nucleus and $\left({ }^{*}\right)$ fibrillar aggregates. Bars represent $2 \mu \mathrm{m}$.

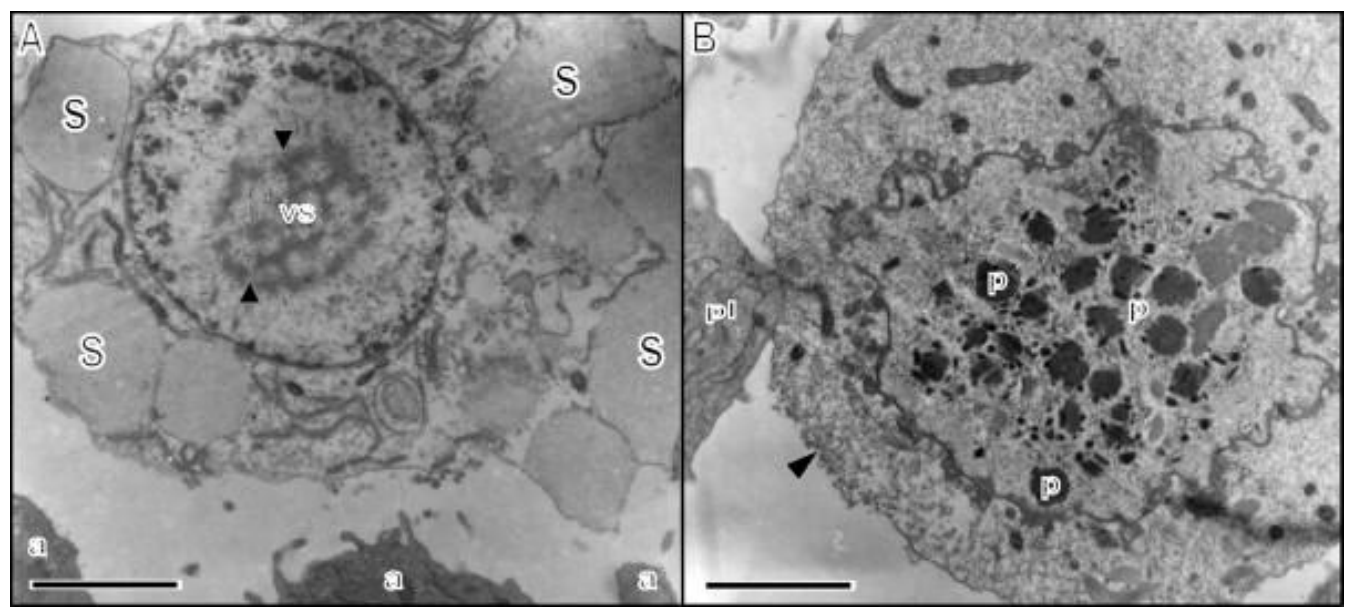

Fig. 7. Necrosis of infected cells. (A) A spherulocyte presenting a mature virogenic stroma (vs) with nucleocapsids assembling (arrowheads). Note the electron density difference between the sph and part of the adjacent cells (a). s, spherules. (B) An oenocytoid presenting PIBs assembling ( $p$ ). A portion of the plasma membrane was disrupted and part of the cytoplasmic content was extruded (arrowhead). A plasmatocyte $(\mathrm{pl})$ is adhered to the oenocitoyd surface. Bars represent $3 \mu \mathrm{m}$. 


\subsection{DNA oligonucleosomal fragmentation assay}

Agarose gel electrophoresis of hemocytes DNA revealed that for mock- (not shown) and AgMNPV-infected insects, there was no DNA fragmentation (Fig. 8A). For vApAg, ladders were not visualized, but smears were found at 48 and $72 \mathrm{~h}$ p.i., periods when apoptosis was more evident (Fig. 8B).
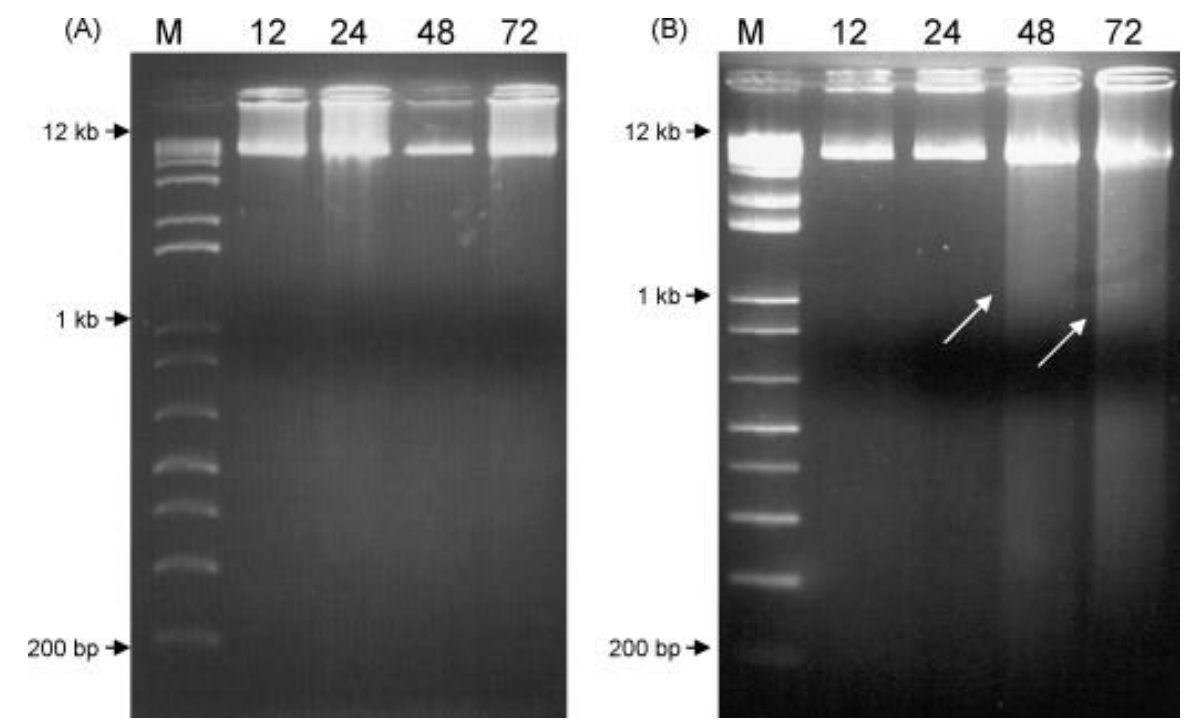

Fig. 8. Three percent agarose gel electrophoresis of DNA extracted from A. gemmatalis larval hemocytes infected with AgMNPV (A) and vApAg (B). Each lane contains approximately $2 \mu \mathrm{g}$ of DNA. M, 1 kb plus DNA ladder. Arrows indicate smears. Numbers indicate hours post-infection.

\section{Discussion}

By studying baculovirus interactions with their hosts, intriguing questions can be elucidated related to the specificity of infection, such as the diversity of survival strategies developed by both viruses and insects over millions of years of coevolution. In this scenario, the knowledge about apoptosis as a defense mechanism in insects and its regulation by baculoviruses are important results in this field.

In this work, we have demonstrated that intrahaemocoelic infection of A. gemmatalis larvae with vApAg causes apoptosis in hemocytes after $24 \mathrm{~h} \mathrm{p.i.,} \mathrm{with} \mathrm{the} \mathrm{occurrence} \mathrm{of}$ progeny production (BVs and PIBs). Despite massive apoptosis at 48 and $72 \mathrm{~h} \mathrm{p.i.,} \mathrm{but} \mathrm{in}$ correlation to the occurrence of progeny production, BV doses of 102 PFU/larva or more induce disease development and death of up to $100 \%$ of larvae. However, vApAg LD50 is sixfold higher than the one for AgMNPV, which shows correlation between apoptosis occurrence and vApAg infectivity decrease. In comparison to intrahaemocoelic infection with AgMNPV BV, the mean time to death and the LT50 has been extended in an average of 3 days for a same 
mortality rate (50 or $100 \%$ of death), an evidence that apoptosis may retard the advance of the systemic infection.

For orally infected A. gemmatalis larvae, it was also demonstrated infectivity reduction for vApAg. The LC50 of VApAg PIBs is five times higher than the LC50 of AgMNPV, the mean time to death was always higher for vApAg in comparison to AgMNPV in a same concentration, as well as the mortality and LT50 values. Despite we did not investigate vApAg apoptosis induction by oral infection, the induction of apoptosis by intrahaemocoelic infection and the evident infectivity reduction demonstrated for the two ways of infection permit us to correlate this with a putative apoptosis occurrence in A. gemmatalis larvae orally infected by vApAg.

For other systems, apoptosis can reduce more drastically the infectivity in vivo. In S. frugiperda larvae, 1000-fold more BV of ACMNPV p35- and 25-fold more PIBs are required for a LD50 in comparison to the wild-type or revertant viruses (Clem and Miller, 1993 and Clem et al., 1994). We have shown by electron microscopy that AcMNPV p35- does not replicate well in UFL-AG 286 cells or in A. gemmatalis hemocytes ( Silveira et al., 1999 and Silveira et al., 2005). In comparison to our data, where similar differences for LD50 and LC50 between vApAg and AgMNPV were found, we can attribute this to the high susceptibility of A. gemmatalis hemocytes to BVs from both wt and mutant virus and the progeny production occurrence despite cell death. For S. frugiperda, it has been shown that hemocytes are not a good way for systemic infection spread of AcMNPV, which may be related to the severe infectivity reduction ( Clarke and Clem, 2002). However, Haas-Stapleton et al. (2003), using a same source of S. frugiperda larvae and AcMNPV strains, have shown a high sensitivity of this insect and its hemocytes to viral infection. The divergence of the data presented by the two groups was attributed to differences in handling techniques.

The temporal sequence of $\mathrm{VApAg}$ morphogenesis in $\mathrm{A}$. gemmatalis hemocytes were similar to that observed for UFL-AG-286 cells ( Silveira et al., 1999) for AgMNPV in hemocytes ( Silveira et al., 2004) and for AgMNPV in other cells (Matos et al., 1999 and Pombo et al., 1998). However, symptoms appear earlier through intrahaemocoelic infection than by oral infection, once a high number of BVs is available to infect hemocytes, bypassing natural barriers and defenses such as midgut digestive juices, peritrophic membrane (Granados, 1980) and midgut cell sloughing ( Hoover et al., 2000).

Cell fragmentation in apoptotic bodies started at $12 \mathrm{~h}$ p.i., but a higher number of apoptotic cells were observed at 48 and $72 \mathrm{~h} \mathrm{p.i.,} \mathrm{which} \mathrm{indicates} \mathrm{a} \mathrm{slight} \mathrm{delay} \mathrm{compared} \mathrm{to}$ UFL-AG-286 cells infected with vApAg (Silveira et al., 1999). On agarose gels, there were smears that suggest hemocyte DNA fragmentation at these times, but it was not possible to visualize ladders, as shown for UFL-AG-286 cells (Silveira et al., 1999). Contrary to in vitro 
conditions, the relative number of apoptotic cells in hemolymph must be lower than in cell culture because of cell turnover and putative differences of susceptibility for the diverse types of hemocytes. Besides this, the intense phagocytosis that occurs in hemolymph may promote a faster secondary degradation of apoptotic bodies DNA into random-size fragments. Together, these factors may have hindered oligonucleosomal fragment resolution and visualization in the gel.

Once cell fragmentation occurred at late times post-infection, the virus cycle of replication was not completely abrogated, allowing BV and PIB production, which correlates with a slighter increase of 6 and 5-fold in vApAg LD50 and LC50, respectively. The VApAg progeny obtained in UFL-AG-286 cells was reduced 100 times when compared to the wild-type virus (Castro and Ribeiro, 2001), showing that apoptosis is correlated with a dropping in progeny production in vitro. Preliminary studies of BVs titration in hemolymph after intrahaemocoelic infection indicate that there is no significant difference between AgMNPV and vApAg levels of progeny production in hemolymph for 48 and $72 \mathrm{~h} \mathrm{p.i.,} \mathrm{however,}$ additional data is necessary to confirm this tendency. It is possible that in other tissues vApAg does not replicate as well as it does in hemocytes, which may be the determinant of larval death delay.

Besides the usual way of cell fragmentation into apoptotic bodies, at late times postinfection some cells presented nuclear disruption and cell architecture disorganization, associated with an exacerbated expansion of the nuclear envelope. Cytoskeleton changes triggered by baculoviral infection per se (Pombo et al., 1998) associated with apoptosis may be the cause of this unusual event in A. gemmatalis hemocytes.

We have found that all hemocyte types of $A$. gemmatalis presented signs of infection, but gh2 appeared to be more resistant to baculovirus infection, as shown previously for the wild-type virus ( Silveira et al., 2004). So, there is no difference between AgMNPV and vApAg in relation to the capacity of infection for the different types of hemocytes. Despite infection, PIB assembly and chromatin condensation, sph appear not to be fragmented into apoptotic bodies, a property that may be somewhat related to the unusual morphology of this hemocyte type.

The infection by vApAg generated phagocytic responses by pl and gh1. Both hemocyte types phagocytosed free virions, PIBs, cell remnants, apoptotic bodies and entire cells. Previous observations for these cells infected by AgMNPV revealed $\mathrm{pl}$ as the only cell to phagocytose entire cells (Silveira et al., 2004), which was more frequent for vApAg also.

Another event previously reported for intrahaemocoelic infection with AgMNPV and observed for vApAg-infected hemocytes was the necrosis of infected cells, which presented 
mature virogenic stroma or polyhedra. Together, phagocytosis and necrosis of infected hemocytes are clues for a putative recognition of these virus-infected cells as altered self, and the triggering of cytotoxic responses against them besides apoptosis. Alternatively, necrosis might simply mean that virus is killing the cell. However, for cultivated cells infected with AgMNPV, membrane rupture and necrosis are generally observed only when the cells are full of PIBs and fibrillar aggregates, and not before the total completion of the viral cycle, as frequently observed in this and in the previous study (Silveira et al., 2004).

Until now, cellular immune responses described against baculoviruses comprises virus uptake in hemolymph, encapsulation and melanization of tracheal infection foci by hemocytes. It has been demonstrated to be important for the circumvention of AcMNPV infection in Helicoverpa zea and Manduca sexta, as an organism-level strategy of resistance ( Trudeau et al., 2001, Washburn et al., 1996 and Washburn et al., 2000). Besides this, the hemocytes resistance to infection and replication per se is a limiting factor to baculovirus spread in organisms ( Trudeau et al., 2001).

For many years, apoptosis induced by mutant baculoviruses in cultivated insect cells had been correlated with infectivity reduction in vivo (Clem, 2001), however only recently this type of cell death was reported in baculovirus-infected insects. AcMNPV was shown to induce apoptosis in diverse tissues of a non-permissive host (S. litura) ( Zhang et al., 2002). The same happened for a p35- AcMNPV recombinant in S. frugiperda, which was correlated to infectivity reduction ( Clarke and Clem, 2003b). More recently we have described apoptosis induction in A. gemmatalis larval hemocytes by a p35- AcMNPV recombinant that was also correlated to infectivity reduction ( Silveira et al., 2005). These reports confirmed apoptosis as an important anti-viral response in insects and one determinant of host species spectrum ( Clarke and Clem, 2003a and Clem, 2001) and so does the present work.

\section{Conclusion}

This work brought a detailed description of the effects caused by an apoptosisinducing baculovirus in A. gemmatalis hemocytes. It was shown that despite apoptosis induction, vApAg replicates in these cells, with the occurrence of phagocytosis of apoptotic bodies, virions, phagocytosis and necrosis of infected cells. Apoptosis occurrence associated to vApAg infection was correlated with a delay in larval death and infectivity reduction in comparison to AgMNPV-2D wild-type virus, with a difference around five and six times between the LC50 and LD50 for the two viruses. This report reinforces the anti-viral function of 
apoptosis in insects and demonstrated also the occurrence of other putative anti-viral responses, represented by phagocytosis and necrosis of infected cells.

\section{Acknowledgements}

We are grateful to Dr. F. Moscardi (Embrapa Soja) for supplying Anticarsia gemmatalis eggs and larvae and Victor H.S. Tibúrcio for assistance in bioassays. This work was supported by CAPES, CNPq, FAP/DF, FINATEC and PRONEX.

\section{References}

Aljanabi, S.M., Martinez, I., 1997. Universal and rapid salt extraction of high quality genomic DNA for PCR-based techniques. Nucleic Acids Res. 25, 4692-4693.

Ashe, P.C., Berry, M.D., 2003. Apoptotic signaling cascates. Prog. NeuroPsychopharmacol. Biol. Psychiatry 27, 199-204.

Carpes, M.P., de Castro, M.E., Soares, E.F., Villela, A.G., Pinedo, F.J., Ribeiro, B.M., 2005. The inhibitor of apoptosis gene (iap-3) of Anticarsia gemmatalis multicapsid nucleopolyhedrovirus (AgMNPV) encodes a functional IAP. Arch. Virol. 150, 1549-1562.

Castro, M.E.B., Ribeiro, B.M., 2001. Production of viral progeny in insect cells undergoing apoptosis induced by a mutant Anticarsia gemmatalis nucleopolyhedrovirus. Microbiol. Res. 156, 369-376.

Clarke, T.E., Clem, R.J., 2002. Lack of involvement of haemocytes in the establishment and spread of infection in Spodoptera frugiperda larvae infected with the baculovirus Autographa californica M nucleopolyhedrovirus by intrahaemocoelic injection. J. Gen. Virol. 83, 15651572.

Clarke, T.E., Clem, R.J., 2003a. Insect defenses against virus infection: the role of apoptosis. Int. Rev. Immunol. 22, 401-424.

Clarke, T.E., Clem, R.J., 2003b. In vivo induction of apoptosis correlating with reduced infectivity during baculovirus infection. J. Virol. 77, 2227-2232.

Clem, R.J., 2001. Baculoviruses and apoptosis: the good, the bad and the ugly. Cell Death Differ. 8, 137-143.

Clem, R.J., Miller, L.K., 1993. Apoptosis reduces both the in vitro replication and the in vivo infectivity of a baculovirus. J. Virol. 67, 3730-3738.

Clem, R.J., Fechheimer, M., Miller, L.K., 1991. Prevention of apoptosis by a baculovirus gene during infection of insect cells. Science 254, 1388-1390.

Clem, R.J., Robson, M., Miller, L.K., 1994. Influence of infection route on the infectivity of baculovirus mutants lacking the apoptosis-inhibiting gene p35 and the adjacent gene p94. J. Virol. 68, 6759-6762. 
Dai, X., Shi, X., Pang, Y., Su, D., 1999. Prevention of baculovirus-induced apoptosis of BTI-Tn5B1-4 (Hi5) cells by the p35 gene of Trichoplusia ni multicapsid nucleopolyhedrovirus. J. Gen. Virol. 80, 1841-1845.

Finney, D.J., 1971. Probit Analysis, third ed. Cambridge University Press, New York. Granados, R.R., 1980. Infectivity and mode of action of baculoviruses. Biotechnol. Bioeng. 22, 1377-1405.

Granados, R.R., Guoxun, L., Derksen, A.C.G., McKennna, K.A., 1994. A new insect cell line from Trichoplusia ni (BTI-Tn-5B1-4) susceptible to Trichoplusia nisingle enveloped nuclear polyhedrosis virus. J. Invertebr. Pathol. 64, 260-266.

Grasela, J.J., McIntosh, A.H., 1998. In vitro and in vivo host range of Anticarsia gemmatalis multiple nuclear polyhedrosis virus. In Vitro Cell. Dev. Biol. 34, 79-83.

Greene, G.L., Leppla, N.C., Dickerson, W.A., 1976. Velvetbean caterpillar: a rearing procedure and artificial medium. J. Econ. Entomol. 69, 487-548.

Haas-Stapleton, E.J., Washburn, J.O., Volkman, L.E., 2003. Pathogenesis of Autographa californica M nucleopolyhedrovirus in fifth instar Spodoptera frugiperda. J. Gen. Virol. 84, 2033-2040.

Hoover, K., Washburn, J.O., Volkman, L.E., 2000. Midgut-based resistance of Heliothis virescens to baculovirus infection mediated by phytochemicals in cotton. J. Insect Physiol. 46, 999-1007.

Johnson, D.W., Maruniak, J.E., 1989. Physical map of Anticarsia gemmatalis Nuclear Polyhedrosis Virus (AgMNPV-2) DNA. J. Gen. Virol. 70, 1877-1883.

Kerr, J.F.R., Wyllie, A.H., Currie, A.R., 1972. Apoptosis: a basic biological phenomenon with wide-ranging implications in tissue kinetics. Br. J. Cancer 26, 239-257.

Matos, T.G.T., Giugliano, L.G., Ribeiro, B.M., Bao, S.N., 1999. Structural and ultrastructural studies of Anticarsia gemmatalis midgut cells infected with the baculovirus $A$. gemmatalis nucleopolyhedrovirus. Int. J. Insect Morphol. Embriol. 28, 195-201.

Mead, G.P., Ratcliffe, N.A., Renwrantz, L.R., 1986. The separation of insect hemocyte types on Percoll gradients: methodology and problems. J. Insect Physiol. 32, 167-177.

Means, J.C., Penabaz, T., Clem, R.J., 2007. Identification and functional characterization of AMVp33, a novel homolog of the baculovirus caspase inhibitor p35 found in Amsacta moorei entomopoxvirus. Virology 358, 436-447.

Morales, L., Moscardi, F., Sosa-Gomez, D.R., Paro, F.E., Soldorio, I.L., 2001. Fluorescent brighteners improve Anticarsia gemmatalis (Lepidoptera: Noctuidae) nucleopolyhedrovirus (AgMNPV) activity on AgMNPV susceptible and resistant strains of the insect. Biol. Control. 20, 247-253.

Moscardi, F., 1999. Assessment of the application of baculoviruses for control of Lepidoptera. Ann. Rev. Entomol. 44, 257-289.

Oliveira, J.V.C., Wolff, J.L.C., Garcia-Maruniak, A., Ribeiro, B.M., Castro, M.E.B., Souza, M.L., Moscardi, F., Maruniak, J.E., Zanotto, P.M.A., 2006. Genome of the most widely used viral 
biopesticide: Anticarsia gemmatalis multiple nucleopolyhedrovirus. J. Gen. Virol. 87, 32333250 .

O’Reilly, D.R., Miller, L.K., Luckow, V.A., 1992. Baculovirus Expression Vectors. A Laboratory Manual, first ed. W.H. Freeman and Company, New York.

Pombo, V., Velloso, L.M., Ribeiro, B.M., Bao, S.N., 1998. Structural and 'ultrastructural changes during the infection of UFL-AG-286 cells with the baculovirus AgMNPV. J. Invertebr. Pathol. 72, 239-245.

Ribeiro, B.M., Souza, M.L., Kitajima, E.W., 1998. Taxonomia, caracterização molecular e bioqu'ımica de v'ırus de insetos. In: Alves, S.B. (Ed.), Controle Microbiano de Insetos. FEALQ, Piracicaba, pp. 481-507.

Sieburth, P.J., Maruniak, J.E., 1988a. Growth characteristics of a continuous line from the velvetbean caterpillar Anticarsia gemmatalis Hubner (Lepidoptera: Noctuidae). In Vitro Cell. Dev. Biol. 24, 195-198.

Sieburth, P.J., Maruniak, J.E., 1988b. Susceptibility of an established cell line of Anticarsia gemmatalis (Lepidoptera: Noctuidae) to three nuclear polyhedrosis viruses. J. Invertebr. Pathol. 52, 453-458.

Silveira, E.B., Ribeiro, B.M., Bao, S.N., 1999. Morphological studies of 'apoptosis in insect cells infected with $\mathrm{vApAg}$, an Anticarsia gemmatalis nucleopolyhedrovirus mutant. J. Submicrosc. Cytol. Pathol. 31, 543-554.

Silveira, E.B., Ribeiro, B.M., Bao, S.N., 2003. Characterization of larval 'haemocytes from the velvetbean caterpillar Anticarsia gemmatalis(Hubner) (Lepidoptera: Noctuidae). J. Submicrosc. Cytol. Pathol. 35, 129-139.

Silveira, E.B., Cordeiro, B.A., Ribeiro, B.M., Bao, S.N., 2004. Morphological characterization of Anticarsia gemmatalis $\mathrm{M}$ nucleopolyhedrovirus infection in haemocytes from its natural larval host, the velvetbean caterpillar Anticarsia gemmatalis (Hubner) (Lepidoptera: Noctuidae). Tissue Cell 36, 171-180.

Silveira, E.B., Cordeiro, B.A., Ribeiro, B.M., Bao, S.N., 2005. In vivo apoptosis 'induction and reduction of infectivity by an Autographa californica multiple nucleopolyhedrovirus p35recombinant in hemocytes from the velvet bean caterpillar Anticarsia gemmatalis (Hubner) (Lepidoptera: Noctuidae). Res.Microbiol. 156, 1014-1025.

Trudeau, D., Washburn, J.O., Volkman, L.E., 2001. Central role of haemocytes in Autographa californica $\mathrm{M}$ nucleopolyhedrosis pathogenesis in Heliothis virescens and Helicoverpa zea. J. Virol. 75, 996-1003.

Washburn, J.O., Kirkpatrick, B.A., Volkman, L.E., 1996. Insect protection against viruses. Nature 383, 767. Washburn, J.O., Haas-Stapleton, E.J., Tan, F.F., Beckage, N.E., Volkman, L.E., 2000. Co-infection of Manduca sexta larvae with polydnavirus from Cotesia congregata increases susceptibility to fatal infection by Autographa californica M nucleopolyhedrovirus. J. Insect Physiol. 46, 179-190. 
Zhang, P., Yang, K., Da'ı, X., Pang, Y., Su, D., 2002. Infection of wild-type Autographa californica multicapsid nucleopolyhedrovirus induces in vivo apoptosis of Spodoptera litura larvae. J. Gen. Virol. 83, 3003-3011. 